\title{
Assessment of Climate Change Impacts on the Water Resources of Megech River Catchment, Abbay Basin, Ethiopia
}

\author{
Endalkachew Abebe ${ }^{1}$, Asfaw Kebede ${ }^{2}$ \\ ${ }^{1}$ Department of Soil and Water Resource Management, Woldia University, Woldia, Ethiopia \\ ${ }^{2}$ School of Natural Resource and Environmental Engineering, Institute of Technology, Haramaya University, Dire Dawa, Ethiopia \\ Email: *endalkabebe@yahoo.com
}

How to cite this paper: Abebe, E. and Kebede, A. (2017) Assessment of Climate Change Impacts on the Water Resources of Megech River Catchment, Abbay Basin, Ethiopia. Open Journal of Modern Hydro$\log , 7,141-152$.

https://doi.org/10.4236/ojmh.2017.72008

Received: July 6, 2016

Accepted: April 14, 2017

Published: April 17, 2017

Copyright ( 2017 by authors and Scientific Research Publishing Inc. This work is licensed under the Creative Commons Attribution International License (CC BY 4.0).

http://creativecommons.org/licenses/by/4.0/

\begin{abstract}
This study was aimed to assess the impact of climate change on the water resource of Megech river catchment. In this study, large scale regional climate model (REMO) output was downscaled statistically to metrological variables at a daily resolution using SDSM model version 5.11. We noticed that statistical downscaling smooth out the bias between REMO output and observed data. According to the projected climate data, the maximum temperature is likely to have an increasing trend $+0.57^{\circ} \mathrm{C}$ while the minimum temperature shows a decreasing trends $-0.61^{\circ} \mathrm{C}$. There is no clear trend for precipitation, both increasing and decreasing trend observed in the catchment. The HBVLight hydrological model was successfully calibrated (1991-1995) and validated (1998-2000) using current climatic inputs and observed river flows. The overall performances of the model was good at monthly time scale both on calibration $(\mathrm{NSE}=0.91)$ and validation $(\mathrm{NSE}=0.86)$. Future discharge (20152050) was simulated using statistically downscaled 20 ensembles climate scenario data for both $\mathrm{A} 1 \mathrm{~B}$ and $\mathrm{B} 1$ scenarios. HBV-Light model simulation results showed a reduction of the peak discharge in August and September.
\end{abstract}

\section{Keywords \\ HBV-Light Model, Megech, REMO, SDSM}

\section{Introduction}

Climate change refers to a change in the state of the climate that can be identified by changes in the mean and/or the variability of its properties and that persists for an extended period, typically decade or more [1]. Climate model projections show an increase in the global mean near-surface air temperature [2]. 
It is now widely acknowledged that climate change will have impacts on water resources availability and management throughout the world, in the near and longer terms. Some of the sectors under concern include urban water supply, irrigated agriculture and hydropower production [1] [3].

According to [4], the current climate variability is already imposing a significant challenge to Ethiopia by affecting food security, water and energy supply, poverty reduction and sustainable development efforts, as well as by causing natural resource degradation and natural disasters. Therefore, assessing the impact of climate change on the water resource of Megech river catchment will be expected to have importance to be considered in development plans in water resources, agriculture and to overcome the impacts of intensifying recurrent droughts. This gives an opportunity to plan appropriate adaptation of measure $s$ that must be taken ahead of time based on the projected climate change.

Several studies have attempted to evaluate the impacts of climate change in Ethiopia [5] [6] [7]. Most of this studies used Global Climate Model (GCM) which has a coarser resolution and some degree of uncertainty. In addition, these studies did not use model ensemble predictions, which provide a means of forecasting robust simulations for weather and climate prediction uncertainties. No Impact assessment of climate change study had been performed for the Megech catchment of the Abbay basin, even though there have been studies conducted on other part of the Abay basin [6] [7] [8]. The objective of this study was to assess the impact of climate change on the water resource of Megech River catchment.

\section{Materials and Methods}

\subsection{Study Area}

Megech catchment is located in the Northwest part of Ethiopia between $12^{\circ} 29^{\prime} 00^{\prime \prime}$ to $12^{\circ} 43^{\prime} 40^{\prime \prime}$ latitude and $37^{\circ} 23^{\prime} 53^{\prime \prime}$ to $37^{\circ} 33^{\prime} 35^{\prime \prime}$ longitude with an approximation altitude range between 1849 and 2942 m.a.s.l. The catchment covers a total surface of $513 \mathrm{~km}^{2}$ as it shown in Figure 1. The annual rainfall ranges between $896 \mathrm{~mm}$ and $1592 \mathrm{~mm}$. The monthly maximum temperature is between $21^{\circ} \mathrm{C}$ and $27^{\circ} \mathrm{C}$, and the monthly minimum temperature is between $10^{\circ} \mathrm{C}$ and $13^{\circ} \mathrm{C}$. The study area had been selected due to the reason that it is one of the major tributaries of Lake Tana and no impact assessment studies had been done on the catchment.

\subsection{Methodology}

In this work, the output variables from REMO (Regional Climate Model) for both emission scenarios of $\mathrm{A} 1 \mathrm{~B}$ and $\mathrm{B} 1$ were statistically downscaled by using Statistical Downscaling Model (SDSM) version 5.11. HBV-Light hydrological model was calibrated and validated using historical climate data of three stations (Ambagiorgis, Gondar and Maksengit) and observed discharge data of Megech river. The downscaled future scenario 20 ensembles data of both REMO A1B 


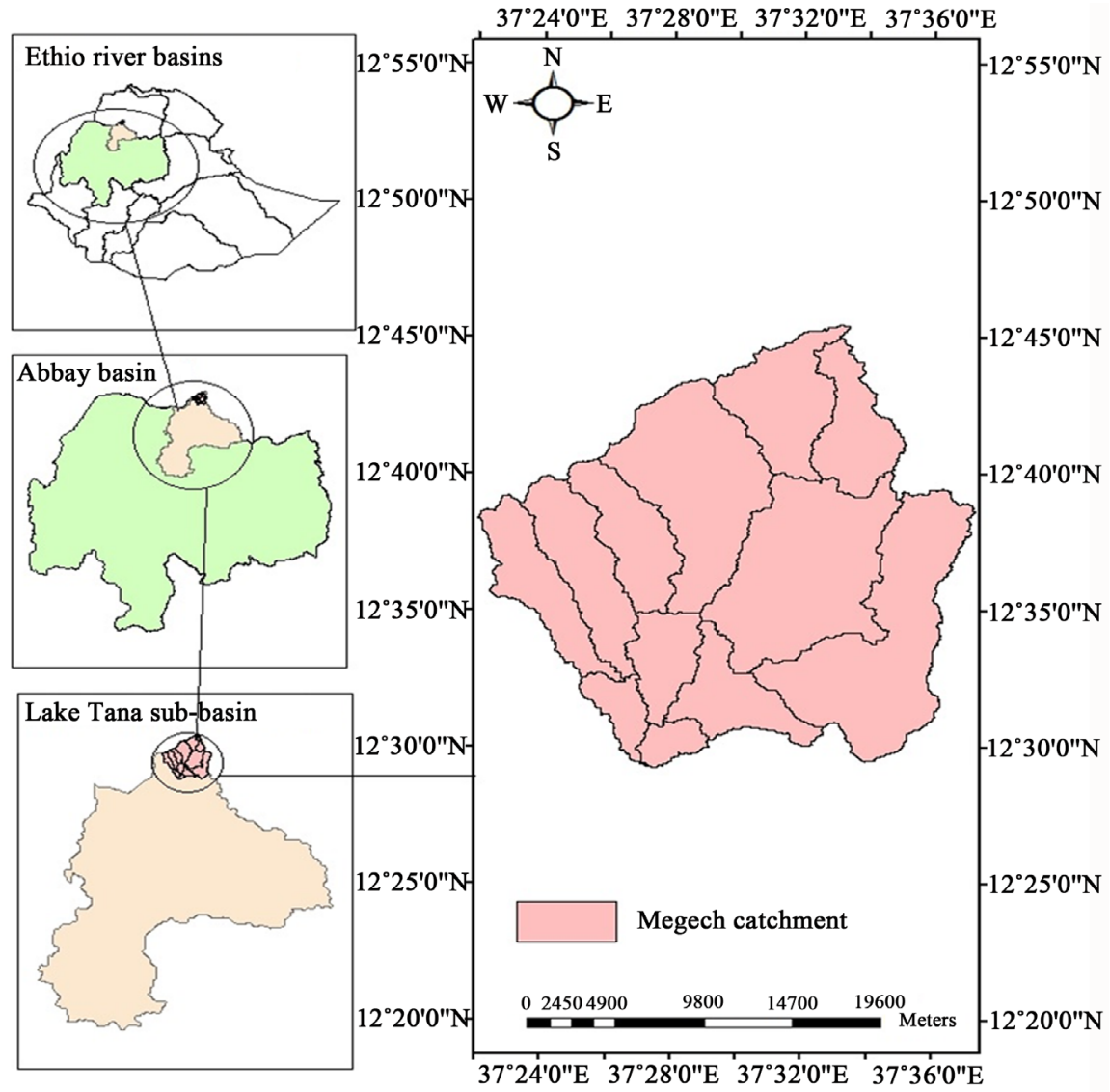

Figure 1. Location of Megech catchment.

and B1 scenario were used as an input for HBV-Light model to assess catchment hydrological response to climate change.

\subsubsection{Climate Model and Downscaling}

For this study the climate scenario data (A1B and B1) were extracted from REMO model based on longitude and latitude that had grid resolution of $50 \mathrm{~km}$ $\left(0.5^{\circ}\right.$ latitude by $0.5^{\circ}$ longitude grid size).The coarser climate data (REMO output) further downscaled in to station level by using statistical downscaling model (SDSM version 5.1.1) and these downscaled data was taken directly as an input to the hydrological model to assess the future climate change impact on hydrology of the catchment.

\subsubsection{REMO Model}

The regional climate model REMO is a hydrostatic regional climate model developed at the Max Planck Institute for Meteorology on the basis of the former operational weather forecast model Europa-model of the German Weather Service (DWD) [9]. In addition, the physical parameterization package of the general circulation model ECHAM4 has been implemented in REMO. REMO quantification of the IPCC A1B and B1 (Medium-Low Emission) scenarios for the years 2015-2050 was used in this study after being statistically downscaled to the local scale using the SDSM 5.11. 


\subsubsection{Statistical Downscaling Model}

According to Wilby et al. [10] empirical downscaling involves developing a quantitative relationship between large-scale atmospheric variables (predictors) and local surface variables (predictands). For this study the REMO grid nodes data were takes as predictors and the station data were taken as predictands. The catchment was covered by 8 REMO raster nodes. Among those 3 grids nodes were used for downscaling. The base line data for the base period were from 3 stations in and around the Megech catchment within the range of 30 to 21 years period from 1971-2000 and 1980-2000 respectively. The first 20 (1971-1990) to 14 (1980-1993) years of data were considered for calibrating SDSM while the remaining 10 (1991-2000) to 7 years (1994-2000) respectively, were used for validation. After calibrating SDSM model, the future climate scenarios (2015-2050) was generated based on the calibrated parameter and large scale predictor (REMO predictor) based on the mean of 20 ensembles for both $\mathrm{A} 1 \mathrm{~B}$ and $\mathrm{B} 1$ scenarios.

\subsubsection{Grid Selection for Statistical Downscaling Model (SDSM)}

The REMO model which covers the area of interest $\left(12^{\circ} 29^{\prime} 00^{\prime \prime} \mathrm{N}\right.$ to $12^{\circ} 43^{\prime} 40^{\prime \prime} \mathrm{N}$ and $37^{\circ} 23^{\prime} 53^{\prime \prime} \mathrm{E}$ to $37^{\circ} 33^{\prime} 35^{\prime \prime} \mathrm{E}$ ) was used in this study. REMO grid outputs data were classified based on their grid location (Latitude and Longitude) with $0.5^{\circ}$ horizontal interval. The catchment was covered by 8 REMO raster nodes as shown in Figure 2. Among those 3 grids nodes were used for downscaling. The grid data were selected as a predictor for a given metrological station and the station data were taken as predictand.

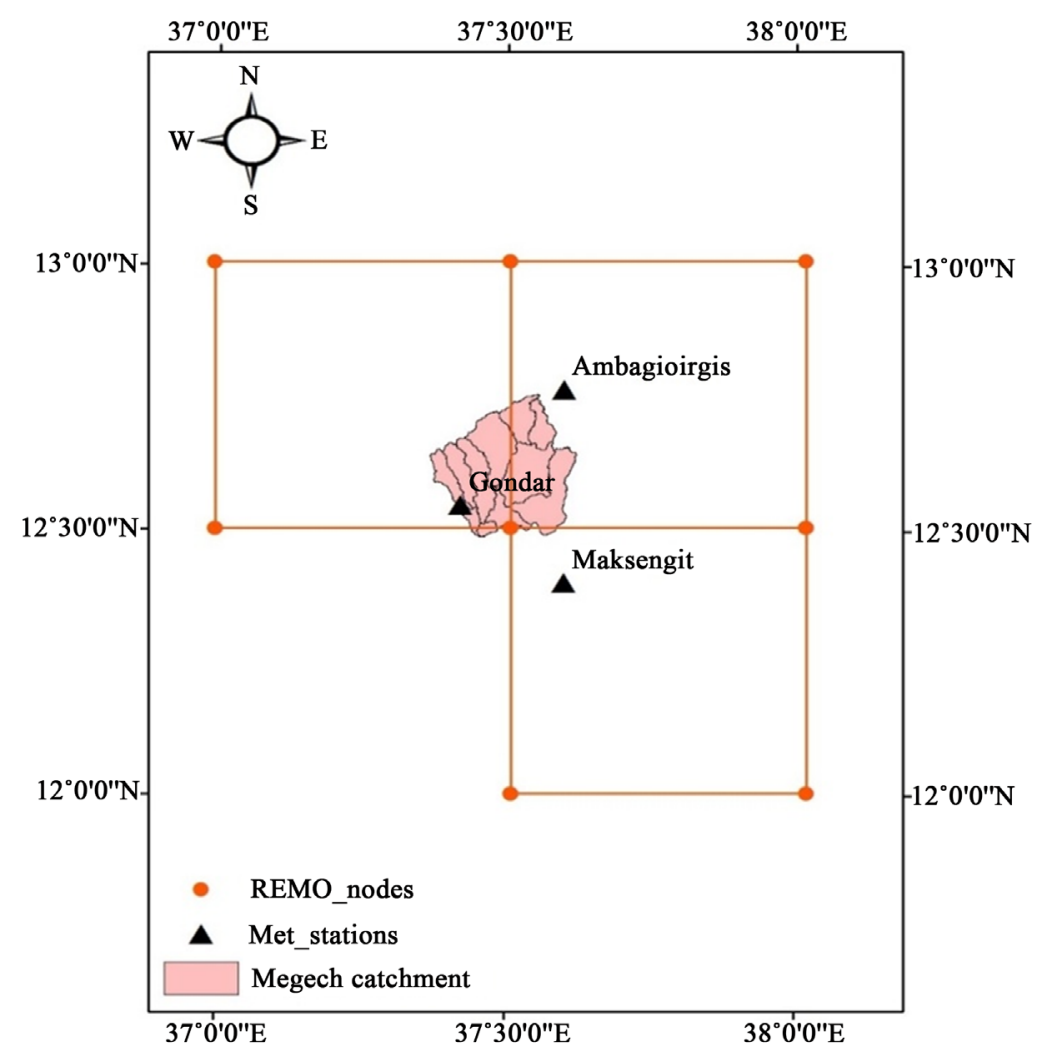

Figure 2. REMO grids selected for the study area. 


\subsubsection{Hydrological Modeling}

To simulate the water balance components of the catchment, HBV-Light model was used. The HBV (Hydrologiska Byråns Vattenbalansavdelning)-Light hydrology model is a widely used conceptual model [11]. It computes runoff from observed daily rainfall, daily temperature, long-term monthly potential evapotranspiration and runoff data. The daily areal rainfall (1991-2000) was calculated by Thiessen polygon method. Potential evapotranspiration for the study area was estimated by the Hargreaves method. The total period of the data that was used for this specific study was 8 years. From this period by using split sample technique $2 / 3^{\text {rd }}$ of the data (1991-1995) were used for calibration and the remaining $1 / 3^{\text {rd }}$ of the data (1998-2000) were applied for validation.

\subsubsection{Model Performance Criteria}

For this particular study, three performance criteria namely Nash and Sutcliffe efficiency (NSE), Coefficient of determination $\left(\mathrm{R}^{2}\right)$ and Relative volume error (RVE) were used. Nash and Sutcliffe efficiency (NSE) was proposed by [12], its value lies between 1.0 (perfect fit) and $-\infty$. Coefficient of determination $\left(R^{2}\right)$ is expressed as [13] the squared ratio between the covariance and the multiplied standard deviations of the observed and predicted. Relative volume error (RVE) can vary between $\infty$ and $-\infty$ but it performs best when a value of 0 (zero) is generated.

\section{Results and Discussion}

\subsection{REMO output Downscaling for the Future Climate Scenarios}

Climate scenarios for future periods (2015-2050) have been developed for two emission scenarios of REMO A1B and B1 based on the mean of 20 ensembles.

\section{1) Maximum temperature}

As it shown in Figure 3 and Figure 4, the mean monthly maximum temperature shown generally an increase trend for future period (2015-2050) for both $\mathrm{A} 1 \mathrm{~B}$ and $\mathrm{B} 1$ scenario in the range of $+0.1^{\circ} \mathrm{C}$ to $+0.51^{\circ} \mathrm{C}$ and $+0.12^{\circ} \mathrm{C}$ to $+0.57^{\circ} \mathrm{C}$ respectively. There will be overall an increasing trend for Gondar station for both $\mathrm{A} 1 \mathrm{~B}$ and $\mathrm{B} 1$ scenario for the period of 2015-2050 in the range of $+0.17^{\circ} \mathrm{C}$ to $+0.8^{\circ} \mathrm{C}$. However Ambagirogis and Maksengit stations show almost no change for both $\mathrm{A} 1 \mathrm{~B}$ and $\mathrm{B} 1$ scenario.

\section{2) Minimum Temperature}

As it revealed in Figure 5 and Figure 6 generally there will be a decreasing trend for mean monthly minimum temperature for Both $\mathrm{A} 1 \mathrm{~B}$ and $\mathrm{B} 1$ scenario in the range of $-0.11^{\circ} \mathrm{C}$ to $-0.61^{\circ} \mathrm{C}$ and $-0.12^{\circ} \mathrm{C}$ to $-0.60^{\circ} \mathrm{C}$ respectively for future window (2015-2050).

\section{3) Precipitation}

As it depicted in Figure 7 and Figure 8, the mean monthly precipitation shows both increasing and decreasing trend for both $\mathrm{A} 1 \mathrm{~B}$ and $\mathrm{d} \mathrm{B} 1$ scenario for future period (2015-2050). It is likely to be increased in the range of $+6.7 \%$ to $+34.5 \%$ and $+11.0 \%$ to $+38.89 \%$ while it is expected to be decreased in the range between 


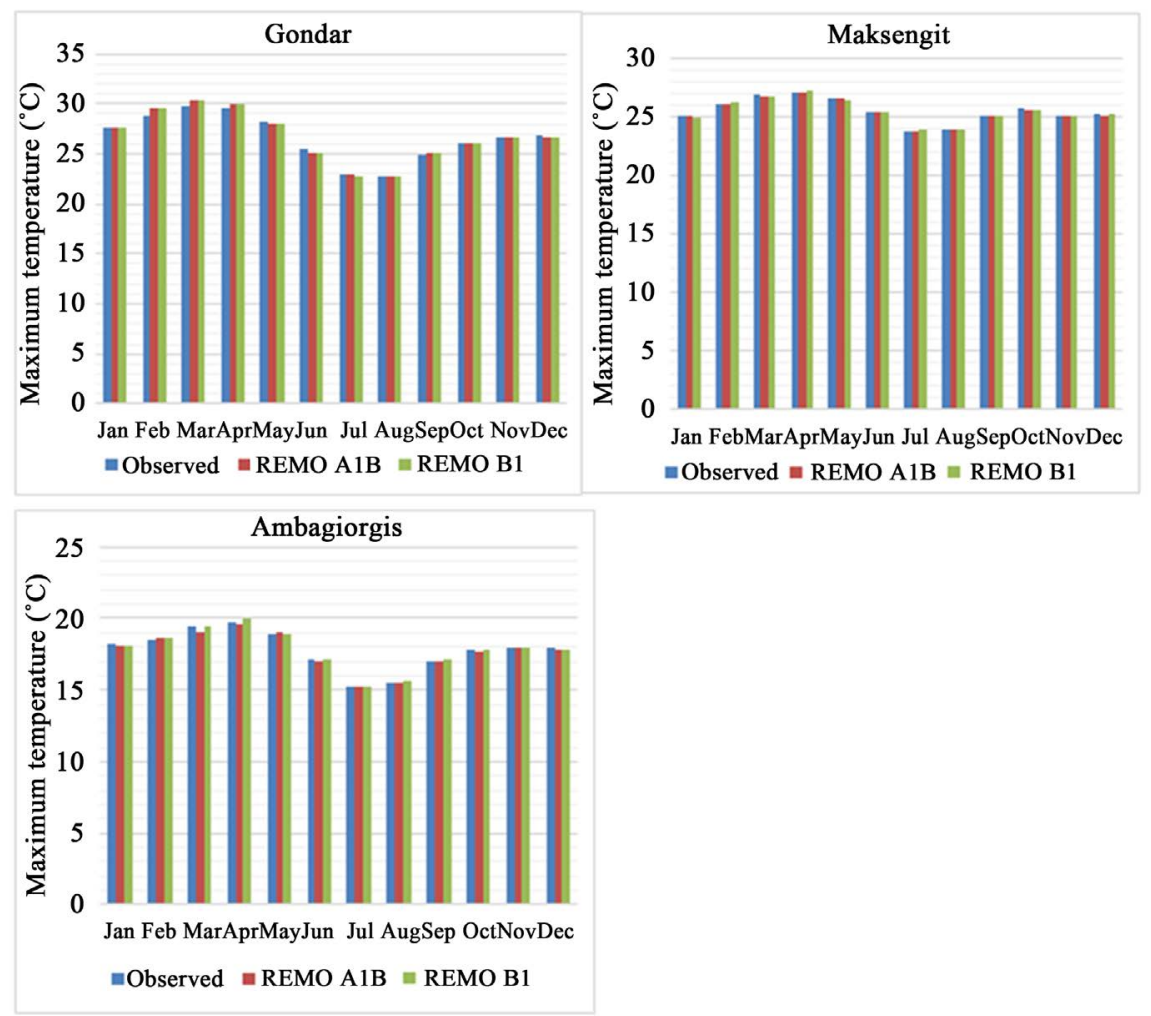

Figure 3. Monthly mean maximum temperature for the baseline period (1971-2000) and REMO A1B and B1 scenarios of selected stations.

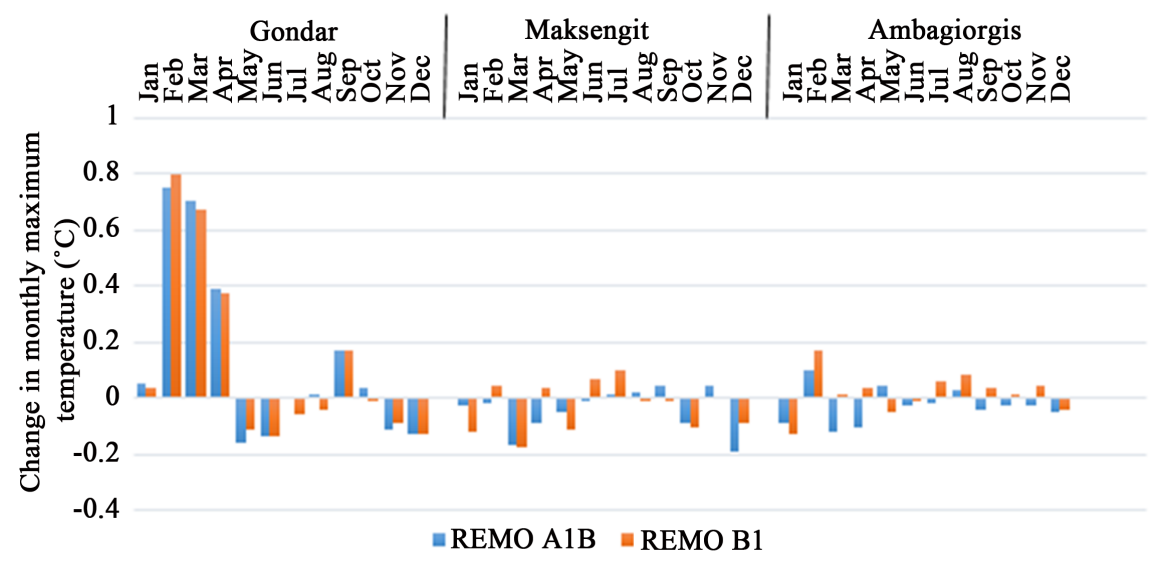

Figure 4. Change anomalies of mean monthly maximum temperature of selected stations for future period (2015-2050) for both A1B and B1 scenarios.

$-1.14 \%$ to $-31.88 \%$ and $-1.6 \%$ to $-36.42 \%$ for $\mathrm{A} 1 \mathrm{~B}$ and $\mathrm{B} 1$ scenarios respectively.

\subsection{Hydrological Model Calibration and Validation}

The calibration and verification of the HBV-Light model were implemented by using split sample technique (1991-1995) data for calibration and the remaining (1998-2000) data for validation. Calibration was done manually by optimizing the model parameters that gave the best possible agreement between observed 


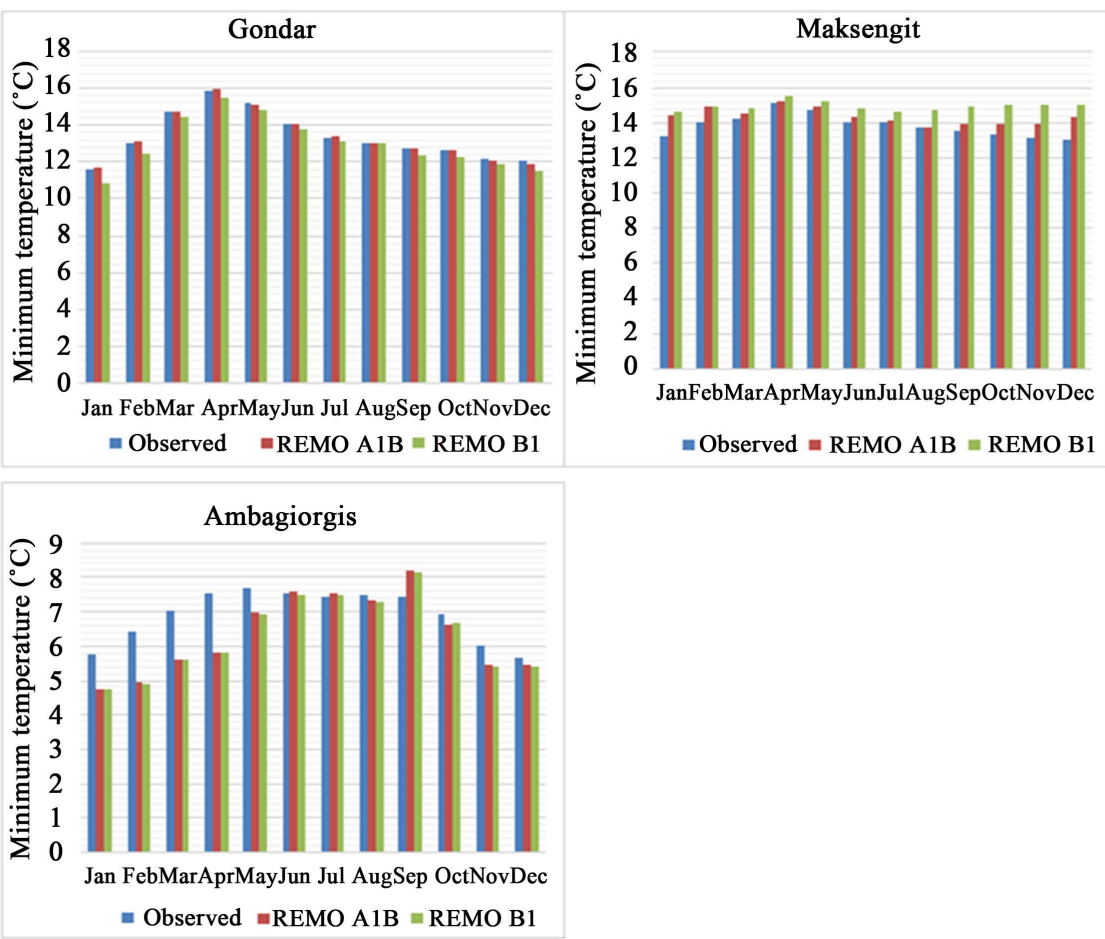

Figure 5. Monthly mean minimum temperature for the baseline period (1971-2000) and REMO A1B and B1 scenarios of selected stations.

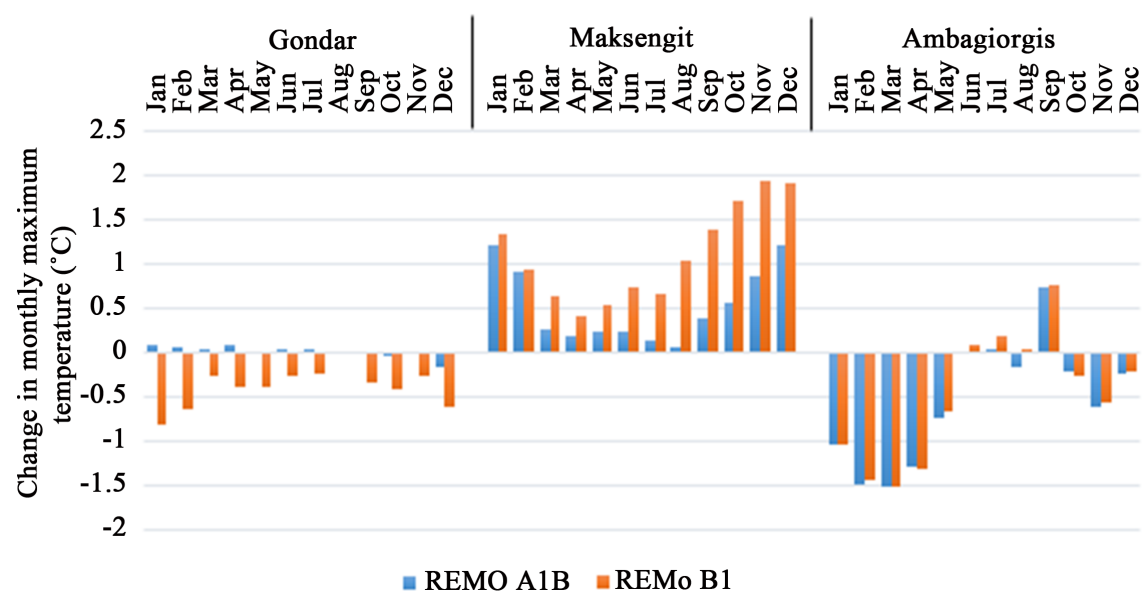

Figure 6. Change anomalies of mean monthly minimum temperature of selected stations for future period (2015-2050) for both A1B and B1 scenarios.

and simulated discharge of a catchment. Due to that several runs had been attempted to select the most optimum parameter set that shows good agreement between observed and simulated discharge. The performance of the model has been evaluated using both graphical and statistical criteria. On graphical analysis the agreement between observed and simulated discharge was evaluated through visual inspection.

The statistical criteria's selected for showed good performance for daily and monthly calibration (with NSE $=0.91$ and $\mathrm{R}^{2}=0.92$ for monthly simulation). In addition, the models were validated using independent data set, which shows 


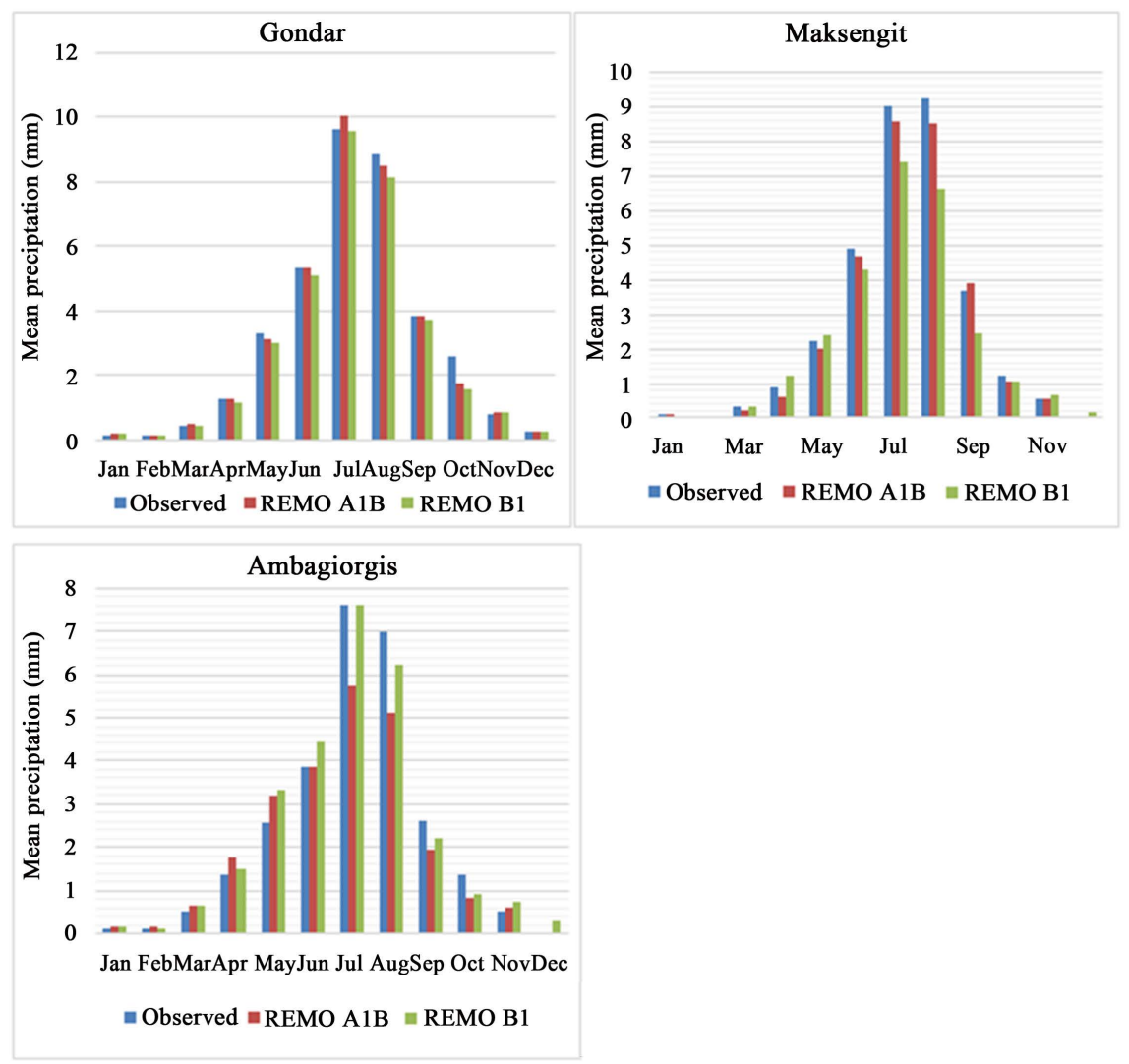

Figure 7. Monthly mean Preciptation for the baseline period and REMO A1B and B1 scenario of selected stations.

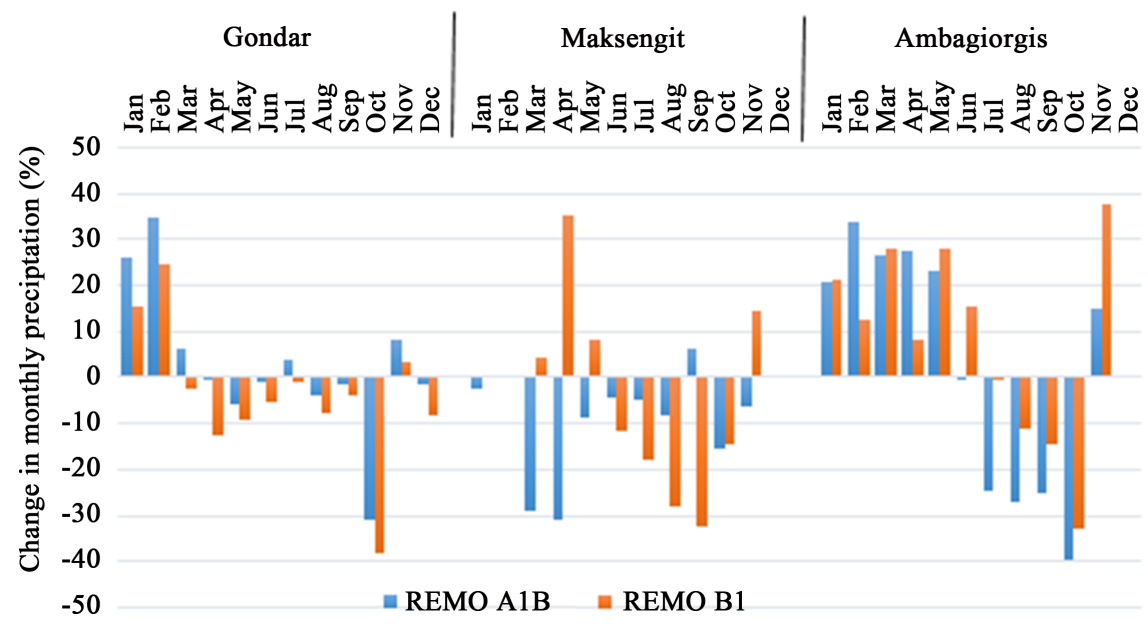

Figure 8. Change anomalies of mean monthly precipitation of selected stations for future period (2015-2050) for both A1B and B1 scenarios.

good agreement for both daily and monthly simulation results (with NSE $=0.86$ and $\mathrm{R}^{2}=0.87$ for monthly simulation). Generally speaking, the results show that the HBV-Light model can reproduce historical daily discharge with an acceptable accuracy. Previous impact assessment studies done using HBV model showed similar result [6] [14] [15]. The calibration and validation result of the HBVLight model is shown in Figure 9 and Figure 10. 


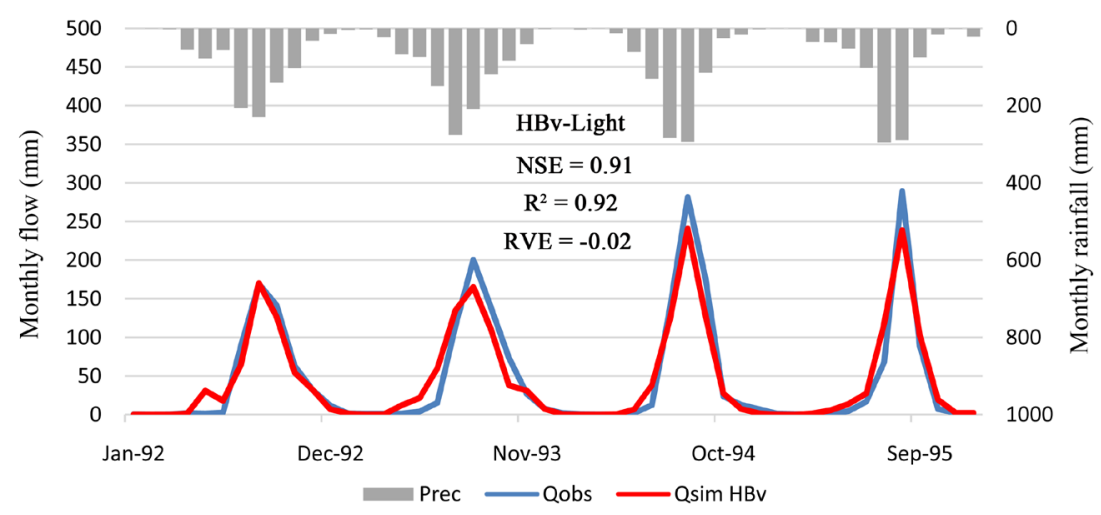

Figure 9. Monthly calibration result of Megech catchment (1992-1995).

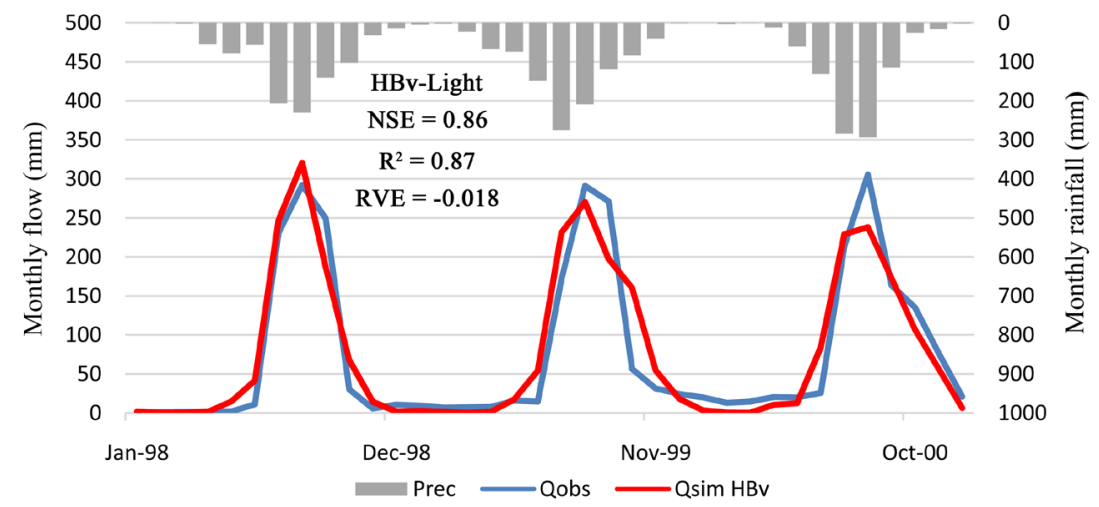

Figure 10. Monthly validation of Megech catchment (1998-2000).

\subsection{Catchment Predicting Hydrological Response of Changed Climate}

For analyzing the catchment response of climate change, 20 ensembles of climate variables (i.e. Precipitation and temperature) for both REMO A1B and B1 scenario were developed). Each 20 ensembles of climate data have been used as an input for simulating the discharge of Megech catchment for future period (20152050). Among the simulated 20 ensembles the maximum and minimum one has been selected to find the range of discharge Change for future period (20152050). As displayed on Figure 11 and Figure 12 the HBV-Light hydrological model showed a reduction in peak discharge (August \& September) for future period (2015-2050. Simulation result showed that there will be a shift in wet season towards May to July. There will a reduction of peak flow for August and September $(-17.47 \%$ to $-30.58 \%)$ this is mainly because for those periods temperature shows no change while Precipitation expected to be fall down up to $-10 \%$. For the low flow (October to December) HBV-Light models shows a decreasing trend. For low flow of the dry season (November to April), since there will be an increment of both maximum temperature $\left(+0.57^{\circ} \mathrm{C}\right)$ and precipitation $(+38.39 \%)$, simulation result showed almost no change except for the month of April which shows an increasing trend for both $\mathrm{A} 1 \mathrm{~B}$ and B1 scenarios.

Generally the mean annual simulated water balance for the observed period and future climate change scenarios is portrayed in Table 1 . The table results are 


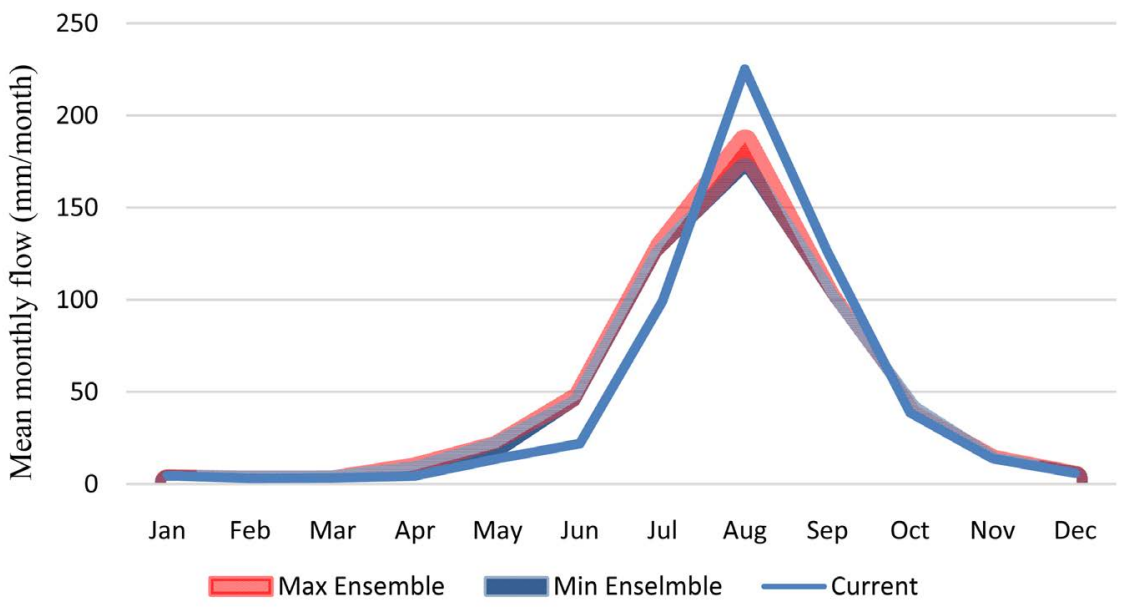

Figure 11. Comparison of current and future period discharge (2015-2050) for maximum and minimum ensembles of REMO A1B Scenario as it simulated by HBV-Light model.

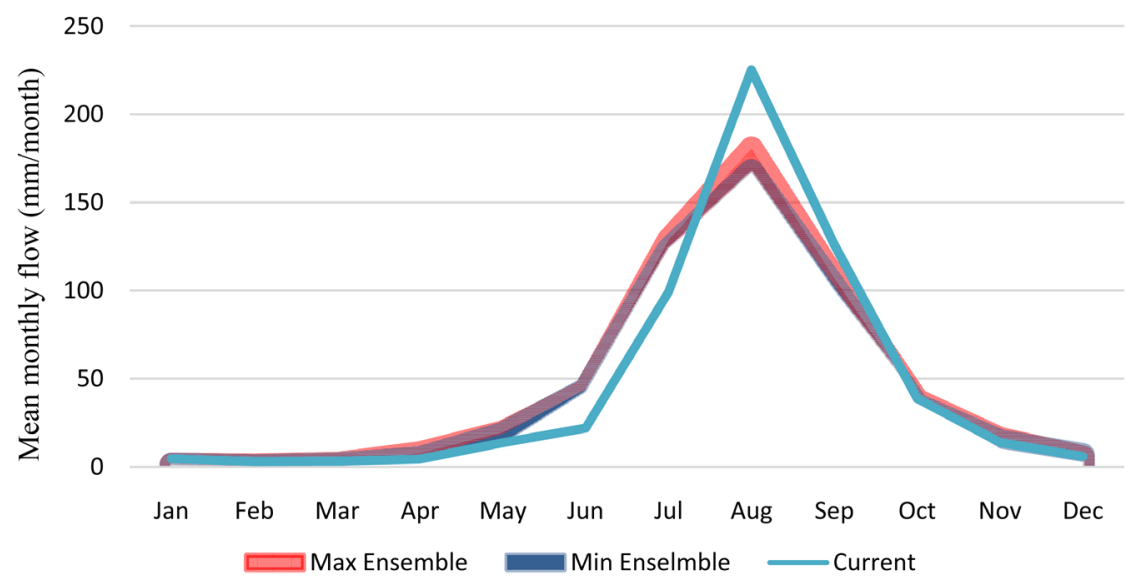

Figure 12. Comparison of current and future period discharge (2015-2050) for maximum and minimum ensembles of REMO B1 Scenario as it simulated by HBV-Light model.

Table 1. Mean simulated annual water balance for the observed period and future climate change REMO A1B and B1 scenarios in the Megech River catchment.

\begin{tabular}{|c|c|c|c|c|c|c|c|}
\hline & & $\mathrm{Q}_{\mathrm{T}}(\mathrm{mm})$ & $\operatorname{ETP}(\mathrm{mm})$ & $\operatorname{ETR}(\mathrm{mm})$ & $\mathrm{Q}_{\mathrm{T}}(\Delta \%)$ & $\operatorname{ETP}(\Delta \%)$ & $\operatorname{ETR}(\Delta \%)$ \\
\hline \multirow{11}{*}{ HBV-Light } & $\begin{array}{c}\text { Observed } \\
(1991-1995, \\
1998-2000)\end{array}$ & 559 & 1424 & 433 & 0 & 0 & 0 \\
\hline & REMO A1B & & & & & & \\
\hline & $2015-2024$ & 545.76 & 1459.13 & 485.62 & -2.37 & +2.46 & +12.15 \\
\hline & $2025-2034$ & 543.78 & 1460.0 & 477.58 & -2.72 & +2.52 & +10.29 \\
\hline & $2035-2044$ & 531.08 & 1463.76 & 475.53 & -4.99 & +2.79 & +9.82 \\
\hline & $2045-2050$ & 534.60 & 1462.49 & 477.08 & -4.36 & +2.70 & +10.18 \\
\hline & REMO B1 & & & & & & \\
\hline & $2015-2024$ & 539.62 & 1435.6 & 487.16 & -3.46 & +0.81 & +12.50 \\
\hline & $2025-2034$ & 540.0 & 1439.8 & 478.20 & -3.39 & +1.10 & +10.43 \\
\hline & $2035-2044$ & 531.80 & 1438.71 & 478.11 & -4.86 & +1.03 & +10.41 \\
\hline & $2045-2050$ & 527.20 & 1446.25 & 481.95 & -5.68 & +1.56 & +11.30 \\
\hline
\end{tabular}


the averages of the 20 ensemble run for each climate scenario of potential evapotraspiration (ETP), actual evapotraspiration (ETR) and total discharge (QT). Change in percentage $(\Delta \%)$ had been determined by comparing the reference observed period discharge and evpotranspiration from the future scenarios (2015-2050) and it is portrayed in Table 1.

\section{Conclusions and Recommendations}

As the result indicates the mean monthly maximum temperature would increase in the range of $+0.1^{\circ} \mathrm{C}$ to $+0.51^{\circ} \mathrm{C}$ for REMO A1B +0.12 to +0.57 for REMO B1 scenarios. The mean monthly minimum temperature was expected to be decreased in the range of $-0.11^{\circ} \mathrm{C}$ to $-0.25^{\circ} \mathrm{C}$ for REMO A1B and -0.12 to -0.57 for REMO B1 scenarios in all future time horizons (2015-2050). The result of downscaled precipitation showed both increasing and decreasing trend unlike maximum and minimum temperature in all future time horizon (2015-2050). However in the main rainy seasons (July and August) showed a decreasing trend with highest decrease observed in August with 10\% reduction for REMO B1 scenario. The beginning of the rainy seasons (May and June) revealed almost no change while the end of the rainy season (September and October) showed a decreasing trend for both $\mathrm{A} 1 \mathrm{~B}$ and $\mathrm{B} 1$ scenarios in all future time horizon.

The calibration and validation results of HBV-Light shows that the model is able to reproduce discharge with good performance $\left(\mathrm{R}^{2}=0.92, \mathrm{NSE}=0.91 \mathrm{RVE}\right.$ $=0.02$ ). The performances of the model in simulating future discharge (20152050) were tested using downscaled REMO climate scenario data. The hydrological models showed that there will be a reduction of peak flow for August and September (-17.47\% to $-30.58 \%)$. For the low flow (October to December) HBVLight models shows a decreasing trend while for low flow of the dry season (November to April) almost no change will be for both A1B and B1 scenarios.

The study showed that there would be a reduction in precipitation in major rainy season (Kiremit) and an increment of precipitation in Bega season. Coping mechanisms like adaptation actions should be taken in accordance with the present and future scientific studies include: changing the cropping calendar, use of moisture stress resistant crops, adopt different irrigation methods, crop diversification, mixed crop-livestock farming systems, and scaling up the soil and water conservation practices. The catchment water management system should be in accordance with the future trends of rainfall peaks as the temporal shift in peak rainfall showed a direct impact on the flow of Megech river catchment.

According to the study, there would be a reduction in precipitation in major rainy season (Kiremit) and an increment of precipitation in Bega season. Therefore, soil and water conservation activities should be adopted by the community as well as water harvesting structure should be properly designed and applied on the catchment since for the future period temperature and evapotrasnpiration would increase and would cause a reduction in the flow of Megech River.

\section{References}

[1] IPCC (Intergovernmental Panel on Climate Change) (2007) Climate Change 2007: 
the Physical Science Basis. Contribution of Working Group II to the Fourth Assessment Report of the Intergovernmental Panel on Climate Change, Cambridge University Press, Cambridge, UK.

[2] IPCC (Intergovernmental Panel on Climate Change) (2001) Climate Change: The Scientific Basis. In: Houghton, J.T., Ding, Y., Griggs, D.J., Noguer, M., van der Linden, P.J., Dai, X., Maskell, K. and Johnson, C.A., Eds., Technical Summary of the Working Group I Report, Cambridge University Press, Cambridge, UK.

[3] Jasper, K., Calanca, P., Gyalistras, D. and Fuhrer, J. (2004) Differential Impacts of Climate Change on the Hydrology of Two Alpine River Basins. Climate Research, 26, 113-129. https://doi.org/10.3354/cr026113

[4] Tadege, A., Ed. (2007) Climate Change National Adaptation Programme of Action (NAPA) of Ethiopia. Ministry of Water Resources and National Meteorological Agency, Addis Ababa.

[5] Beyene, T., Lettenmaier, D.P. and Kabat, P. (2010) Hydrological Impact of Climate Change on the Nile River Basin: Implication of the 2007 IPCC Scenarios. Climate Change, 100, 433-461. https://doi.org/10.1007/s10584-009-9693-0

[6] Abdo, K.S., Fiseha, B.M., Rientjes, T.H., Gieske, A.S. and Haile, A.T. (2009) Assessment of Climate Change Impacts on the Hydrology of Gilgel Abay Catchment in Lake Tana Basin, Ethiopia. Hydrological Processes, 23, 3661-3669.

[7] Belay, H. (2011) Evaluation of Climate Change Impacts on Hydrology on Selected Catchments of Abbay Basin. MSc Thesis, Institute of Technology, Addis Ababa University, Addis Ababa, Ethiopia.

[8] Mulushewa, Z. (2013) Hydrological Impacts of Climate Change on Lake Tana's Water Balance. MSc Thesis, Faculty of Geo-Information Science and Earth Observation, University of Twenty, The Netherlands.

[9] Jacob, D. (2001) A Note to the Simulation of the Annual and Inter-Annual Variability of the Water Budget over the Baltic Sea Drainage Basin. Meteorology and Atmospheric Physics, 77, 61-73. https://doi.org/10.1007/s007030170017

[10] Wilby, L.R., Zorita, E., Timbal, B., Whetton, P., Mearns, L.O. and Charles, S.P. (2004) Guidelines for Use of Climate Scenario Developed from Statistical Downscaling Methods. Environmental Agency of England and Wales, UK.

[11] Seibert, J. (2005) HBV Light Version 2. User's Manual. Department of Physical Geography and Quaternary Geology, Stockholm University, Stockholm.

[12] Nash, J.E. and Sutcliffe, J.V. (1970) River Flow Forecasting through Conceptual Models, Part I-A Discussion of Principles. Journal of Hydrology, 10, 282-290.

[13] Krause, P., Boyle, D.P. and Bäse, F. (2005) Comparison of Different Efficiency Criteria for Hydrological Model Assessment. Advances in Geosciences, 5, 89-97. https://doi.org/10.5194/adgeo-5-89-2005

[14] Gebreyesus, K. (2014) Impact Assessment of Climate Change on the Hydrology of Gojeb River Catchment in Western Omogibe River Basin, Ethiopia. MSc Thesis, Haramaya University, Haramaya, Ethiopia.

[15] Kebede, A. (2013) Downscaling Climate Model Outputs for Estimating the Impact of Climate Change on Water Availability over the Baro-Akobo River Basin, Ethiopia. Doctoral Dissertation, Bonn University, Germany. 
Submit or recommend next manuscript to SCIRP and we will provide best service for you:

Accepting pre-submission inquiries through Email, Facebook, LinkedIn, Twitter, etc. A wide selection of journals (inclusive of 9 subjects, more than 200 journals)

Providing 24-hour high-quality service

User-friendly online submission system

Fair and swift peer-review system

Efficient typesetting and proofreading procedure

Display of the result of downloads and visits, as well as the number of cited articles Maximum dissemination of your research work

Submit your manuscript at: http://papersubmission.scirp.org/

Or contact ojmh@scirp.org 